\title{
JUDICIAL REVIEW OF GOVERNMENT REGULATIONS IN LIEU OF LAWS PROBLEMS
}

\author{
Ali Marwan Hsb \\ North Sumatra Regional Office of the Ministry of Law and Human Rights \\ Jalan Putri Hijau Number 4 Medan \\ ali_marwan@rocketmail.com
}

\begin{abstract}
The granting of the authority for judicial review of government regulations in lieu of laws to the Constitutional Court through Decision Number 138 / PUU-VII / 2009 in addition to being a legal breakthrough in filling the legal void for reviewing statutory regulations, in practice creates problems. The Method use in thisWhere, the verdict of examining government regulations in lieu of law is unacceptable because the petition loses its object as a result of the passage of government regulations in lieu of law as the object of examination into law.
\end{abstract}

Keywords: Judicial Review, Government Regulations in Lieu of Law, Constitutional Court.

\begin{tabular}{lrl}
\hline Journal History & \\
Received & $:$ & February 26, 2021; \\
Reviewed & $:$ & March 23, 2021; \\
Accepted & $:$ March 29, 2021; \\
Published & $:$ April 14, 2021. \\
\hline Copyright @2020 NLR. All right reserved. \\
\hline
\end{tabular}

\section{INTRODUCTION}

In terms of supervision of legal norms, according to Cappelleti, there are 2 (two) types of supervision commonly carried out in a country, namely judicial review and political review. Both political supervision and judicial supervision are carried out by assessing or examining a statutory regulation whether it contradicts the constitution or higher legislation. ${ }^{1}$

In terms of judicial review, according to Maruarar Siahaan, the function of judicial review must be seen from the opinion of Hans Nawiasky which states that the fundamental norm status (basic norms of the state) is the highest norm which must be a reference for the legal norms that are under it. If there are norms or statutory regulations that are below the basic norms that conflict with the statutory fundamental norms, then there must be a separate mechanism so that deviations that occur can be rectified. This is where the function of the judicial review is to correct legal products under the staats of fundamental norms, laws and regulations under the constitution so that they do not conflict with the statutes of fundamental norms. ${ }^{2}$

\footnotetext{
${ }^{1}$ Lutfil Ansori, Pengujian Peraturan Perundang-undangan, (Malang: Setara Press, 2018), p. 2.

2 Ali Marwan Hsb, Konsep Judicial Review dan Model Pelembagaannya di Berbagai Negara, (Malang: Setara Press, 2017), p. 46-47.
} 
In Indonesia, the construction of the test of legislation by the judiciary (judicial review) in accordance with the provisions of the Constitution of the Republic of Indonesia in 1945 that there are 2 (two) jurisdictions to test the rule of law, namely: Constitutional Court authorized to test law against the Constitution and the Supreme Court which has the power ${ }^{3}$ to test the rule of law under the law against the law. ${ }^{4}$

If this provision is then linked to the type and hierarchy of statutory regulations as stipulated in Article 7 paragraph (1) of Law Number 12 of 2011 concerning the Formation of Legislative Regulations, one of the statutory regulations that is exempt from the authority of examination is government regulations. substitute for law. Where, the Constitutional Court and Supreme Court do not have the authority to examine government regulations in lieu of laws. ${ }^{5}$

The legal vacuum is filled based on the Decision of the Constitutional

${ }^{3}$ Soekanto in Hadita (2020) Power has a very important role because it can determine the fate of millions of people. Both the bad power must always be measured by its usefulness to achieve a goal that has been determined or realized by the community first. Cynthia Hadita, Regional Autonomy Political Politics Of Regional Liability Reports To Regional Representatives In The Implementation Of Local Government, Nomoi Law Review, Volume 1, Issue 1, May 2020, p. 92.

4 Ali Marwan Hsb, "Pengujian Peraturan Pemerintah Pengganti UndangUndang", Jurnal Legislasi Indonesia, Vol. 13, No. 02 - Juni 2016, p. 148.

5 Ali Marwan Hsb, "Judicial Review dan Legislative Review terhadap Peraturan Pemerintah Pengganti Undang-Undang”, Jurnal Legislasi Indonesia, Vol. 17, No. 1 - Maret 2020 , p. 56 .
Court Number 138 / PUU-VII / 2009, where one of the important points of the decision is that the Constitutional Court has the authority to examine government regulations in lieu of laws. However, apart from filling the legal vacuum, this authority in practice actually creates problems. These problems will be discussed in this paper.

\section{METHOD}

This research is a normative legal research. Marzuki in Eka NAM Sihombing (2019) states that the normative juridical legal research method is a method that uses an approach that is based on the main legal material by examining theories, concepts of legal principles, norms, rules of legislation, court decision, agreement. The nature of the research used in this paper is prescriptive, adhering to the characteristics of legal science as an applied science, the prescriptions given in legal research activities must be able and possible to be applied. Therefore what is produced by legal research, even if it is not a new legal principle or a new theory, is at least a new argument. ${ }^{6}$

\section{DISCUSSION}

\section{Historical Judicial Review of Government Regulations in Lieu of Law}

One of the state institutions that was born from the womb of reform is

6 Eka N.A.M Sihombing, Eksistensi Paralegal dalam Pemberian Bantuan Hukum bagi Masyarakat Miskin (The Existence of Paralegals in Providing Legal Aid to the Poor), Jurnal Ilmiah Penegakan Hukum, Vol. 6, No. 1, June (2019). 
the Constitutional Court (MK), where the state institution has a position as a constitutional court. The rule of law is termed rechstaats or the rule of law. ${ }^{7}$ Based on the provisions of the 1945 Constitution of the Republic of Indonesia, the judicial review authority is only exercised by the Constitutional Court and the Supreme Court to review laws and statutory regulations under statute. Meanwhile, the judicial review of government regulations in lieu of laws has a legal vacuum, because it is not the authority of the Constitutional Court or the Supreme Court.

However, this does not mean that there has never been a request for a judicial review of government regulations in lieu of laws. The government regulation in lieu of law that was first tested in the Constitutional Court was the Government Regulation in lieu of Law Number 4 of 2009 concerning Amendments to Law Number 30 of 2002 concerning the Corruption Eradication Commission, where the test is registered with an application No. 136 / PUU-VII / 2009.

In the decision Number $138 /$ PUU-VII / 2009, the Constitutional Court stated that it has the authority to examine government regulations in lieu of laws with the following considerations:

a. whereas the provisions of Article 22 of the 1945 Constitution of the Republic of Indonesia contain:

${ }^{7}$ Andryan, Eka NAM

Sihombing,Penguatan Mahkamah Konstitusi Republik Indonesia Melalui Constitutional Complaint, Jurnal Hukum Perancangan Peraturan Perundang-undangan, Vol. 4 No. 2, November (2018).
1. To give the President the authority to make government regulations in lieu of laws;

2. this authority can only be used if in a compelling emergency;

3. the government regulation in lieu of this law must be approved by the House of Representatives at its next session;

b. b. whereas the 1945 Constitution of the Republic of Indonesia distinguishes between government regulations in lieu of laws and government regulations as referred to in Article 5 paragraph (2) whose purpose is to carry out laws properly. Since government regulations in lieu of laws are regulated in the Chapter on the House of Representatives while the House of Representatives is the holder of the power to form laws, then the material for government regulations in lieu of laws should be material which according to the Basic Law is regulated by law and neither material implementing the law as referred to in Article 5 paragraph (2) of the 1945 Constitution of the Republic of Indonesia and the material for government regulations in lieu of law are also not constitutional material. If there is a vacuum in the law due to various things so that the material of the law has not been processed to become law in accordance with the procedures or provisions that apply in making the law but there are urgent situations and conditions that require legal rules in casu the law to immediately be used to overcome something that happened, Article 22 
of the 1945 Constitution of the Republic of Indonesia provides a special institution by authorizing the President to make Government Regulations (as) in lieu of laws. Making laws to fill the legal vacuum by forming a law as a normal or normal process by starting the stage of submitting a bill by the House of Representatives or by the President will take a long time so that these urgent legal needs cannot be resolved.

c. that therefore a Government Regulation in Lieu of a Law is required if:

1. there is a situation, namely an urgent need to resolve legal problems quickly based on the law;

2. The law that is needed is not yet available so that there is a legal vacuum, or there is a law but it is not sufficient;

3. the legal vacuum cannot be resolved by making laws in the usual procedure because it will take a long time while the urgent situation needs certainty to be resolved;it is thus so that the hope of foaming crunch is not interpreted to the extent that there is danger as by Article 12 of the 1945 Constitution. It is true that the situation of danger by Article 12 of the 1945 Constitution can cause the usual legal process or can not be sorted, the situation but danger is not the only thing circumstances cause the onset of crunch to be sorted by Article 22 paragraph (1) constitution 1945; d. That Article 22 paragraph (1) of the 1945 Constitution states. "In compelling circumstances, the President has the right to stipulate government regulations in lieu of laws". From the formulation of the sentence, it is clear that the government regulation referred to in this article is a substitute for the Law, which means that the material should be regulated in the container of the Law but due to compelling urgency, the 1945 Constitution gives the President the right to stipulate the Perpu and does not grant rights. to the DPR to make regulations in lieu of laws. If the making of regulations is submitted to the DPR, the process in the DPR will take quite a long time because the DPR as a representative institution, the decision making is in the hands of the members, which means that to decide something must go through DPR meetings so that if you have to wait for the DPR's decision, the legal requirement is fast. may not be fulfilled. In addition, by calling it "the President has the right" the impression that the drafting of the Perpu is very subjective because it is a right and depends entirely on the President. The Presidential Decree is indeed in the hands of the President, which means it depends on the President's subjective judgment, however, it does not mean that it is absolutely dependent on the President's subjective judgment because as described above the President's subjective assessment must be based on an objective 
situation, namely the existence of three conditions as a parameter of urgency. that's forcing. In certain cases where the need for a law is urgent to resolve very important state problems that are felt by all nations, the right of the President to enact a Perpu can even become a mandate for the President to enact a Perpu as an effort to resolve the problems of the nation and state;

The Perpu gives birth to legal norms and as new legal norms it will give rise to: (a) new legal status, (b) new legal relationships, and (c) new legal consequences. These legal norms were born since the Perpu was passed and the fate of these legal norms depends on the DPR's approval to accept or reject the legal norms of the Perpu, however, before the DPR's opinion to reject or approve the Perpu was issued, these legal norms are valid and apply as a law. Because it can give rise to legal norms whose binding power is the same as the Law, the Court can test whether it is materially contradictory to the 1945 Constitution. Thus the Court has the authority to examine the Perpu against the 1945 Constitution prior to rejection or approval by the DPR , and after the DPR's approval because the Perpu has become a law. Against the ruling that states that the Constitutional Court is authorized to test government regulations in lieu of the law,
Constitutional Judge Moh. Mahfud MD had different reasons and Constitutional Judge Muhammad Alim had a different opinion.

According to Moh. Mahfud $M D$, if traced from the original intent, interpretation, historic, grammatical interpretation, and legal logic, the Constitutional Court should not be able to carry out a judicial review of government regulations in lieu of laws against the Constitution. Because according to Article 24C paragraph (1) of the 1945 Constitution, the Court only examines laws against the Constitution. The sentence in Article 24C paragraph (1) very clearly only mentions laws and does not mention government regulations in lieu of laws. If the Court were allowed to examine government regulations in lieu of laws, of course the Constitution explicitly mentions this acquisition because formally the 1945 Constitution distinguishes and places different mentions or arrangements between laws and government regulations in lieu of laws; laws are regulated in Article 20, while government regulations in lieu of laws are regulated in Article 22.

It is further stated that the Constitutional Court can test government regulations in lieu of laws through an emphasis on sociological and teleological interpretation. Emphasizing the choice of such interpretation does 
indeed override historical and grammatical interpretations, even out of the original intent of the provisions regarding government regulations in lieu of laws as stipulated in Article 22 of the 1945 Constitution. other articles and principles that also exist in the 1945 Constitution. The choice of this view is based solely on the principle of maintaining the upholding of the constitution, namely: "Not even one second of legislation that has the potential to violate the constitution without can be straightened out or tested through judicial testing".

Meanwhile Muhammad Alim argues that the Constitutional Court should not have the authority to examine the constitutionality of government regulations in lieu of laws on the grounds that Article 24C paragraph (1) of the 1945 Constitution, Article 10 paragraph (1) letter a of Law Number 24 of 2003 concerning The Constitutional Court, and Article 12 paragraph (1) letter a of Law Number 4 of 2004 concerning Judicial Power only states: "examining the law against the constitution".

Apart from fellow

Constitutional Justices, the pros and cons related to the authority of the Constitutional Court to examine government regulations in lieu of laws can also be seen from the opinions of several legal experts. One of them is Jimly
Asshiddiqie. Where according to Jimly Asshiddiqie, as long as it is still in the form of a government regulation in lieu of a law has not yet become a law, even though its position is equal to law, efforts to control government regulations in lieu of law are still the matter of the House of Representatives, not yet a matter for the Court. Constitution. If it becomes a new law it can be tested by the Constitutional Court. However, in order to prevent the President's arbitrary and arbitrary actions from causing victims of more serious injustice, the Constitutional Court should be given the authority to examine government regulations in lieu of laws. ${ }^{8}$

In contrast to Jimly Asshiddiqie, Ni'matul Huda stated that the Constitutional Court does not have the authority to examine government regulations in lieu of laws because the 1945 Constitution does not give the Constitutional Court the authority to examine government regulations in lieu of laws. The 1945 Constitution has explicitly stipulated that the House of Representatives has the authority to examine government regulations in lieu of laws. The need in practice to examine government regulations in lieu of laws should be a serious study for the People's Consultative

${ }^{8}$ Lutfil Ansori, Pengujian Peraturan..., Op. Cit., p. 147. 
Assembly to determine whether or not to change the 1945 Constitution. The Constitutional Court cannot add authority based on necessity in practice of wanting it. The opinion of the Constitutional Court must be submitted to the People's Consultative Assembly, it must be submitted to the People's Consultative Assembly in order to conduct a study of the matter. If the Constitutional Court's need to examine government regulations in lieu of laws is seen as truly urgent, then the amendment to the 1945 Constitution is a solution that must be pursued by the People's Consultative Assembly. ${ }^{9}$

\section{Judicial Review Practices of Government Regulations in Lieu of Laws}

After the Constitutional Court Decision Number 138 / PUU-VII / 2009, there have been several government regulations in lieu of laws that were enacted and promulgated, namely:

1. Government Regulation in lieu of Law Number 1 of 2013 concerning the Second Amendment to Law Number 24 of 2003 concerning the Constitutional Court;

2. Government Regulation in Lieu of Law Number 1 Year 2014 concerning the Election of Governors, Regents and Mayors;

9 Ni'matul Huda, "Pengujian Perpu oleh Mahkamah Konstitusi”, Jurnal Konstitusi, Volume 7, Nomor 5, Oktober 2020, p. 90.
3. Government Regulation in lieu of Law Number 2 of 2014 concerning Amendments to Law Number 24 of 2013 concerning Regional Government;

4. Government Regulation in lieu of Law Number 1 of 2015 concerning Amendments to Law Number 30 of 2002 concerning the Corruption Eradication Commission;

5. Government Regulation in Lieu of Law Number 1 of 2016 concerning Amendments to Law Number 23 of 2002 concerning Child Protection;

6. Government Regulation in Lieu of Law Number 1 Year 2017 concerning Access to Financial Information for Taxation Purposes;

7. Government Regulation in lieu of Law Number 2 of 2017 concerning Amendments to Law Number 17 of 2013 concerning Community Organizations;

8. Government Regulation in Lieu of Law Number 1 Year 2020 concerning State Financial Policy and Financial System Stability for Handling the 2019 Corona Virus Disease (Covid-19) Pandemic and / or in the Context of Facing Threats Endanger the National Economy and / or Financial System Stability;

9. Government Regulation in Lieu of Law Number 2 of 2020 concerning the Third Amendment to Law Number 1 of 2015 concerning Application of Government Regulations in Lieu of Law Number 1 of 2014 concerning Election of Governors, Regents, and Mayors into Law. 
From the government regulations in lieu of the stipulated and promulgated laws, several judicial reviews have been submitted to the Constitutional Court, namely:

1. Government Regulation in Lieu of Law Number 1 Year 2013 concerning Second Amendment to Law Number 24 Year 2003 concerning the Constitutional Court is petitioned for its review to the Constitutional Court in several applications, namely Number 91 / PUU-XI / 2013 filed by Habiburokhman, Number 92 / PUU-XI / 2013 submitted by the Constitutional Lawyers Forum, Number 93 / PUU-XI / 2013 submitted by dr. Salim Alkatiri, and Number 94 / PUU-XI / 2013 submitted by Muhammad Joni, Khairul Alwan Nasution, Fakhrurrozi, Mukhlis Ahmad, Zulhaina Tanamas, Triono Priyo Santoso, Hadi Ismanto, and Baginda Dipamora Siregar. The decisions in the four petitions are the same, namely that they cannot be accepted because the petition has lost its object as a result of the determination of the object of the application, namely Government Regulation in Lieu of Law Number 1 of 2013 concerning the Second Amendment to Law Number 24 of 2003 concerning the
Constitutional Court into law. by Law Number 4 of 2014;

2. Government Regulation in Lieu of Law Number 1 of 2014 concerning Election of Governors, Regents and Mayors and Government Regulations in Lieu of Law Number 2 of 2014 concerning Amendments to Law Number 24 of 2013 concerning Regional Government which are petitioned for review at the Constitutional Court in several applications, namely Number 118 / PUU-XII / 2014 submitted by the Forum for the Study of Law and the Constitution, Number 119 / PUU-XII / 2014 submitted by Yanda Zaihifni Ishak, Heriyanto, and Ramdansyah, Number 125 / PUU-XII / 2014 which were submitted by Edward Dewaruci and Doni Istyanto Hari Mahdi, Number 126 / PUU-XII / 2014 submitted by Edward Dewaruci and Doni Istyanto Hari Mahdi, Number 127 / PUU-XII / 2014 submitted by Didi Supriyanto and Abd. Khaliq Ahmad, Number 129 / PUU-XII / 2014 proposed by Moch. Syaiful, Number 130 / PUU-XII / 2014 proposed by Yanni, and Number 135 / PUU-XII / 2014 submitted by the Islamic Defenders Front. The Constitutional Court later decided on these applications in Decision Number 118-119- 
125-126-127-129-130-135 /

PUU-XII / 2014 whose ruling stated that the petition could not be accepted because the application lost its object as a result of the stipulation of the Regulation Government in Lieu of Law Number 1 of 2014 concerning Election of Governors, Regents and Mayors into law with Law Number 1 of 2015 and Government Regulations in Lieu of Law Number 2 of 2014 concerning Amendments to Law Number 24 of 2013 concerning Regional Government becomes law with Law Number 2 of 2015;

3. Government Regulation in lieu of Law Number 2 of 2017 concerning Amendments to Law Number 17 of 2013 concerning Community Organizations, which was requested for review at the Constitutional Court in several applications, namely: Number: 38 / PUU-XV / 2017 submitted by Afriady Son; Number: 39 / PUU-XV / 2017 proposed by the Spokesperson for Hizbut Tahrir Indonesia, Ismail Yusanto; Number: 41 / PUU-XV / 2017 submitted by the Archipelago Alliance; Number 48 / PUU-XV / 2017 which was submitted by the Sharia Law Alqonuni Foundation; Number 49 / PUU-XV / 2017 proposed by the Islamic Union; Number 50
/ PUU-XV / 2017 proposed by the Spokesperson for the Islamic Defenders Front, Munarman, together with four religious organizations, namely the Indonesian Islamic Da'wah Council, the Indonesian Inter-Islamic Studies Forum Foundation, the Hidayatullah Association, and the Indonesian Muslim Youth Association; and Number 52 / PUU-XV / 2017 submitted by Advocates of Cinta Tanah Air, namely Herdiansyah and Ali Hakim Lubis. These applications are then decided by the Constitutional Court in their respective decisions stating that the petition cannot be accepted because the petition has lost its object as a result of the enactment of Government Regulation in Lieu of Law Number 2 of 2017 concerning Amendments to Law Number 17 of 2013 concerning Community Organizations with Law Number 16 of 2017;

4. Government Regulation in Lieu of Law Number 1 Year 2020 concerning State Financial Policy and Financial System Stability for Handling the Corona Virus Disease 2019 (Covid-19) Pandemic and / or in the Context of Facing Threats Endanger the National Economy and / or Financial System Stability, who was petitioned for review 
to the Constitutional Court in several applications, namely: Number 23 / PUU-XVIII / 2020 submitted by Prof. Dr. M. Sirajuddin Syamsuddin, et al., Number 24 / PUU-XVIII / 2020 submitted by the Indonesian Anti-Corruption Society Association (MAKI), the Mega Bintang Solo Indonesia Foundation 1997, the Indonesian Justice Servant Community Harmony Institute (KEMAKI), Supervisory, Escort, and Indonesian Law Enforcement (LP3HI), and Justice Concerned Legal Aid Association (PEKA), and Number 25 / PUU-XVIII / 2020 submitted by H. Damai Hari Lubis. Application Number 23 / PUU-XVIII / 2020 and Number 24 / PUUXVIII / 2020 are then decided by the Constitutional Court in their respective rulings stating that the petition cannot be accepted because the application has lost its object as a result of the enactment of a Government Regulation in Lieu of Number Number 1 of 2020 concerning State Financial Policy and Financial System Stability for Handling the Corona Virus Disease 2019 (Covid-19) Pandemic and / or in the Context of Facing Threats that Endanger the National Economy and / or Financial System Stability, with Law Number 2 of 2020, while application Number 25 / PUU-XVIII / 2020 was withdrawn by the applicant;

5. Government Regulation in Lieu of Law Number 2 of 2020 concerning the Third Amendment to Law Number 1 of $2015 \quad$ concerning Stipulation of Government Regulations in Lieu of Law Number 1 of 2014 concerning the Election of Governors, Regents and Mayors who are petitioned for review at the Constitutional Court in application Number 44 / PUUXVIII / 2020 submitted by the Community Organization for Solo Citizens Care for General Elections (PWSPP), which then submitted a withdrawal for reasons including: "that Commission II of the DPR of the Republic of Indonesia has approved the Government Regulation in Lieu of Law No. 2 of 2020 becomes law, so that the petition submitted by the Petitioner loses the object being tested.

\section{Problematic Judicial Review of Government Regulations in Lieu of Law}

Initially, the Constitutional Court's power to examine government regulations in lieu of laws can be seen as one way of filling the legal vacuum. Where, if the judicial review authority is linked to the hierarchy of laws and regulations, there will be a legal vacuum in the absence of an authorized 
institution to conduct a judicial review of government regulations in lieu of laws. ${ }^{10}$

Where then, through the Decision of the Constitutional Court Number 138 / PUU-VII / 2009, the Constitutional Court, through its judicial interpretation, stated that government regulations in lieu of laws are the same as laws because the two types of laws and regulations are the same in terms of content and are parallel. hierarchically. Therefore, then, the Constitutional Court stated that the Constitutional Court has the authority to examine government regulations in lieu of laws. ${ }^{11}$

In practice, the Constitutional Court decision which states the authority to examine government regulations in lieu of laws creates problems. Where, the breakthrough of the Constitutional Court actually changes the textual value of the 1945 Constitution which has the potential for constitutional chaos, especially the emergence of potential disputes over power that may result from the examination of government regulations in lieu of laws by the Constitutional Court. Potential disputes that then occur are disputes over the authority to examine government regulations in lieu of laws with the House of Representatives and the potential for neglect of the Constitutional Court decision by the President on examining

\footnotetext{
10 Ali Marwan Hsb, "Pengujian Peraturan..., Op. Cit., p. 150.

11 Ibid.
}

government regulations in lieu of laws issued by the President. ${ }^{12}$

Another problem that arises is that in exercising the authority to examine government regulations reviewing regulations in lieu of laws, it creates a separate dilemma for the Constitutional Court. Whether the Constitutional Court continues its examination of government regulations in lieu of laws or awaits a decision from the House of Representatives whether to accept or reject government regulations in lieu of laws to become law.

This dilemma arises because in the practice of examining government regulations in lieu of laws so far, the Constitutional Court has always stated that the petition cannot be accepted because the petition has lost its object because the government regulation in lieu of law has been passed into law or even the petition is revoked by the applicant because there are signs -a sign that the object of the application will be ratified by the House of Representatives into law.

However, on the other hand, the Constitutional Court still needs to examine government regulations in lieu of laws. Because in practice, there are also government regulations in lieu of laws that are only discussed by the House of Representatives after going beyond the first session period since government regulations in lieu of laws are enacted. If government regulations

\begin{tabular}{lcr}
\hline 12 & Ibnu Sina & \multicolumn{2}{c}{ Chandranegara, } \\
"Pengujian & Perppu terkait & Sengketa \\
Kewenangan Konstitusional antar & Lembaga \\
Negara: Kajian atas Putusan MK Nomor & MK \\
138/PUU-VII/2009, Jurnal Yudisial, Volume 5, \\
Nomor 1, April 2012, p. 14.
\end{tabular}


in lieu of laws are not reviewed by the Constitutional Court, it is very possible that one day there will be government regulations in lieu of laws that are enacted but the House of Representatives does not discuss them quickly and is stalling for time for various reasons, even though government regulations are in lieu of laws it contains things that are against the constitution. ${ }^{13}$

\section{CONCLUSION}

Based on the above discussion, it can be concluded that the Constitutional Court's breakthrough in testing government regulations in lieu of laws in practice creates problems. Where, in every verdict of testing government regulations in lieu of law, the verdict is unacceptable because the application loses its object where the government regulation in lieu of law as the object of examination has been passed into law or withdrawn by the applicant because he already knows the petition. will be declared unacceptable.

However, the absence of the Constitutional Court's authority to examine government regulations in lieu of laws also raises problems if one day a government regulation in lieu of law contains material that contradicts the constitution, but the House of Representatives does not discuss government regulations in lieu of law and slacking off.

\footnotetext{
13 Dissenting Opinion Hakim Konstitusi Moh. Mahfud MD dalam Putusan Mahkamah Konstitusi Nomor 138/PUUVII/2009.
}

\section{REFERENCES}

Andryan, Eka NAM Sihombing, Penguatan Mahkamah Konstitusi Republik Indonesia Melalui Constitutional Complaint, Jurnal Hukum Perancangan Peraturan Perundang-undangan, Vol. 4 No. 2, November (2018).

Ansori, Lutfil., Pengujian Peraturan Perundang-undangan, Malang: Setara Press, 2018.

Chandranegara, Ibnu Sina., "Pengujian Perppu terkait Sengketa Kewenangan Konstitusional antar Lembaga Negara: Kajian atas Putusan MK Nomor 138/PUUVII/2009”, Jurnal Yudisial, Volume 5, Nomor 1, April 2012.

Hadita, Cynthia., Regional Autonomy Political Politics Of Regional Liability Reports To Regional Representatives In The Implementation Of Local Government, Nomoi Law Review, Volume 1, Issue 1, May (2020).

Hsb, Ali Marwan., "Judicial Review dan Legislative Review terhadap Peraturan Pemerintah Pengganti Undang-Undang”, Jurnal Legislasi Indonesia, Vol. 17, No. 1 - Maret 2020.

Hsb, Ali Marwan., "Pengujian Peraturan Pemerintah Pengganti Undang-Undang”, Jurnal Legislasi Indonesia, Vol. 13, No. 02 - Maret 2016.

Hsb, Ali Marwan., Konsep Judicial Review dan Model Pelembagaannya di Berbagai Negara, Malang: Setara Press, 2017. 
Huda, Ni'matul., "Pengujian Perpu oleh

Mahkamah Konstitusi”, Jurnal

Konstitusi, Volume 7, Nomor 5,

Oktober 2010. 